\title{
COMPETITIVENESS ANALYSIS OF CZECH AGRARIAN FOREIGN TRADE IN THE CONTEXT OF WORLD AGRARIAN MARKET AND AGRARIAN TRADE OF EU-27 COUNTRIES
}

\author{
M. Svatoš, L. Smutka
}

Received: September 27, 2010

\begin{abstract}
SVATOŠ, M., SMUTKA, L.: Competitiveness analysis of Czech agrarian foreign trade in the context of world agrarian market and agrarian trade of EU-27 countries. Acta univ. agric. et silvic. Mendel. Brun., 2010, LVIII, No. 6, pp. 503-514

This paper analyses the commodity structure of Czech (CR) agrarian trade in relation to the EU countries. An emphasis is put on comparative advantages of particular aggregations from the view-point of their application on the EU internal market. This analysis is based on an evaluation of comparative advantages by means of a modified Balassa index. It is studied in two stages, for the internal EU market and the world market. The analysis results are then shown in a graph. Subsequently, the authors implement an idea arising from a BCG matrix on the results of the graphic presentation. The aim is to identify those aggregations (SITC, rev. 3) which are or have a potential to be a pillar of agri-business (ie, the "cash cows" and "stars"), and vice versa to show the aggregation which are non-prospective in the long term or problematic (ie, the "dogs" and "problem children"). As start are identified as those aggregations which are characterised by the highest growth rate of comparative advantage value. From the analysis results, changes are apparent if we compare the CR trade commodity structure in relation to the EU countries. Findings also concern the development of comparative advantages and following CR specialisation on trade with certain aggregations.
\end{abstract}

competitiveness, agrarian trade, Czech Republic, world, EU, analysis, commodity structure

Foreign trade is historically the oldest and still an important part of the external economic relationships. Its impact on the economic development of individual countries has deepened considerably over the whole period since WW2; international trade development belongs among the most dynamic elements of the development of the world economy in recent decades. As such, it represents not only a dynamic development on a quantitative level, but also, from the viewpoint of structural changes of individual countries, the complex of international trade flows. In harmony with the conclusions of classical, neo-classical as well as modern foreign trade theories, it can be stated that at present, foreign trade is one of the decisive factors influencing economic growth of both the individual countries as well as the world economy (Jeníček and Krepl, 2009).

Agrarian foreign trade is a significant part of the world economy even if its share in world trade is continuously decreasing, and is currently at the level of about $5 \%$ to $7 \%$. For the EU countries, agrarian trade in both the forms of the intra-trade and the extra-trade represents a very important part of the Common Trade Policy and the Common Agrarian Policy (Svatoš, 2008).

The commitment of the Common Agricultural Policy led to unprecedented changes in the economic environment - in agriculture as well as in the processing industry. New members lost the op- 
portunity to regulate the original price level of agricultural products supported by the national border protection and export subsidies (Tomšík and Rosochatecká, 2007).

The CR is one of the new EU members (it became a part of EU in 2004). It is a country with a long agrarian tradition. Its agrarian trade has been developing in the long term and continues to adapt to the constantly changing conditions of the European and world market since the origin of the CR in 1993. In 2004, the CR became a member of the European Union which very significantly changed the position of the agrarian sector in society. Furthermore, there were also considerable changes which affected the agricultural production trade. Because the CR become one of twenty seven EU members, it also become a part of the common market of the EU states.

Nevertheless, there are considerable differences among the individual EU countries, mainly in the relationship of the new EU member states to the old ones (European Commission, 2010).

This article analyses the export commodity structure of CR agrarian trade in relation to the EU countries with the aim of identifying those aggregations which are the most important for the trade with a given group of countries, and the most prospective from the view-point of orientation of Czech agrarian foreign trade (in this case the export).

The agrarian export of the Czech Republic has developed very dynamically over time. Expressed in current USD prices, the export value decreased five times from about 1 billion USD in 1993 to more than 5 billion USD in 2008. In 1993-2009, a summary value of agrarian and food goods exported from the Czech Republic amounted to approximately 35 billion USD, whereas an average year-onyear growth rate of export value approached a limit $10 \%$ yearly. Dominant items of Czech export in the monitored period were S3-022, S3-048, S3-112, S3122, S3-001, S3-041, S3-081, S3-073, S3-054, S3-062,
S3-061, S3-111, S3-012, S3-098 and S3-071. (Particular items also share "significantly" in the world and Union trade as a whole). The share of the particularly mentioned items of Czech export in the value of exports in the world markets and the EU countries market was at a level exceeding 1\% in the monitored period. In the case of some aggregations, the share in the above mentioned global markets is even higher. The share of these items in the resulting export value in 1993-2009 reached about $77 \%$. The most dynamically growing items of agrarian export (a relative change) in the monitored years were aggregations S3-043, S3-121, S3-016, S3-044, S3-071, S3-041, S3-111, S3-122, S3-074 and S3-421 (in the case of these aggregations the export value had increased throughout the monitored period in current dollar prices more than ten times). The share of these aggregations in the growth of agrarian export value reached about 30\% in the observed years. Regarding the real growth of export value (an absolute change), the following aggregations shared in the growth of the value from about 65\% (S3-022, S3-048, S3-122, S3-041, S3-112, S3-081, S3-073, S3-111, S3001 and $53-062)$.

\section{MATERIALS AND METHODS}

This paper is devoted to the problems of analysis of the commodity structure development of CR agrarian and food trade. The agrarian trade analysis is based on an evaluation of the data on development of agrarian foreign trade during 1993-2009. The data source is the UN Comtrade database of the United Nation Organization. The chosen nomenclature is SITC rev. 3 from 2002. It divides agrarian trade into 44 basic items - aggregations representing the agrarian trade commodity structure (UN Comtrade, 2010).

The commodity structure of agrarian trade is analysed from both the points of view of its' own value

\begin{tabular}{lll}
\hline S3-001 LIVE ANIMALS & S3-043 BARLEY, UNMILLED & S3-073 CHOCOLATE, OTH. COCOA \\
PREP & S3-074 TEA AND MATE \\
S3-011 BOVINE MEAT & S3-044 MAIZE UNMILLED & S3-075 SPICES \\
S3-012 OTHER MEAT, MEAT OFFAL & S3-045 OTHER CEREALS, UNMILLED & S3-081 ANIMAL FEED STUFF \\
S3-016 MEAT, ED. OFFL, DRY, SLT, SMK S3-046 MEAL, FLOUR OF WHEAT, MSLN S3-08 & S3-017 MEAT, OFFL. PRPD, PRSVD, NES S3-047 OTHER CEREAL MEAL, FLOURS S3-091 MARGARINE AND SHORTEN. \\
S3-022 MILK AND CREAM & S3-048 CEREAL PREPARATIONS & S3-098 EDIBLE PROD. PREPRTNS,NES \\
S3-023 BUTTER, OTHER FAT OF MILK & S3-054 VEGETABLES & S3-111 NON-ALCOHOL. BEVERAGE \\
S3-024 CHEESE AND CURD & S3-056 VEGTABLES, PRPD, PRSVD, NES & S3-112 ALCOHOLIC BEVERAGES \\
S3-025 EGGS, BIRDS, YOLKS, ALBUMIN S3-057 FRUIT, NUTS EXCL. OIL NUTS & S3-121 TOBACCO, UNMANUFACT. \\
S3-034 FISH, FRESH, CHILLED, FROZN & S3-058 FRUIT, PRESERVED, PREPARED & S3-122 TOBACCO, MANUFACTURED \\
S3-035 FISH, DRIED, SALTED, SMOKED & S3-059 FRUIT, VEGETABLE JUICES & S3-411 ANIMAL OILS AND FATS \\
S3-036 CRUSTACEANS, MOLLUSCS & S3-061 SUGARS, MOLASSES, HONEY & S3-421 FIXED VEG. FAT, OILS, SOFT \\
S3-037 FISH ETC. PREPD, PRSVD. NES & S3-062 SUGAR CONFECTIONERY & S3-422 FIXED VEG. FAT, OILS, OTHER \\
S3-041 WHEAT, MESLIN, UNMILLED & S3-071 COFFEE, COFFEE SUBSTITUTE & S3-431 ANIMAL, VEG. FATS, OILS, NES \\
S3-042 RICE & S3-072 COCOA & \\
\hline
\end{tabular}


development, and the viewpoint of its' own competitiveness (by means of modified Balassa index (Balassa, 1965) of particular items of Czech agrarian export, both on the internal EU market and the world market. An understanding of the structure of agrarian exports of individual countries, and the also the world trade structure, is necessary for the use of the comparative advantage analysis (Krugman and Obstfeld, 2006).

The values of trade flows for needs of the analysis were monitored in USD (in current prices without use of a deflator). Basic statistical-mathematical tools were used, such as: basic index, chain index, geometrical mean, arithmetical mean and absolute value difference. The analysis of Czech agrarian trade competitiveness on the world and EU market was performed by means of the calculation of RCA index (Utkulu and Seymen, 2004), calculated separately for the internal EU market and for the world market.

\section{RCA - indicator of export advantages}

RCAI $=\frac{\frac{x_{i j}}{x_{w j}}}{\frac{\Sigma x_{i}}{\Sigma x_{w}}}$,

where:

$\mathrm{x}_{\mathrm{ij}}$ - export of country "i" and commodity "j"

$\mathrm{x}_{\mathrm{wj}}$ - export of group of countries " $\mathrm{w}$ " and commodity "j"

$\Sigma \mathrm{x}_{\mathrm{i}}$ - total export of country "i"

$\Sigma \mathrm{x}_{\mathrm{w}}$ - total export of group of countries

If:

RCA $>1$ (comparative advantage)

$\mathrm{RCA}<1$ (comparative disadvantage)

$\mathrm{RCA}=0$ (it is dealt neither with advantage nor disadvantage).

The evaluation of development of CR agrarian export competitiveness was carried out at four time levels. The first time level includes the interval 1993-2009. The second includes the period before the CR accession to the EU - i.e. 1999-2003. The third time level implies the period after the CR joining the EU - i.e. 2004-2008. The year 2009 is monitored as an individual separate interval because, regarding impacts of the worldwide economic crisis, this year is atypical and is not suitable for an analysis of agrarian trade development after the accession to the EU.

The results of the RCA index analysis are subsequently presented in a graph where the $x$ axis represents the RCA index values for the world market and the $y$ axis shows the RCA index values for the internal market of the EU-27 countries. Based on the calculated values, the particular aggregations of agrarian trade are distributed in four quadrants. If the aggregations have a revealed competitive advantage only on the world market, they are placed in the bottom right quadrant (quadrant III). The aggregations with a revealed competitive advantage only on the EU-27 market are situated in the upper left quadrant (quadrant I). If an aggregation has no comparative advantage, it is located in the bottom left quadrant (quadrant II). At last, the most fundamental group of aggregations with a revealed competitive advantage on both EU-27 market and the world market is placed in the upper right quadrant (quadrant IV).

In the second stage, the particular aggregations are evaluated on the basis of their share in the general agrarian foreign trade of the CR, and furthermore, on the basis of an average growth rate of export value of particular aggregations in 1999-2008. Subsequently, the results are presented in a graph which represents an analogy of the BCG matrix (Kotler (2007)) - i.e. particular quadrants represent the cash cows (a high share in the general agrarian export and a low growth rate of export value); stars (a high share in the general agrarian export and a high growth rate of export value); dogs (a low share in the general agrarian export and a low growth rate of export value) and problem children (a low share in the general agrarian export and a high growth rate of export value). The description is adapted to the characteristics of the researched problems, of course.

From the results of both these analyses it is possible to identify those aggregations which are the most prospective for the CR agrarian export not only from a point of view of the comparative advantage, but also their on their share of the market and the average growth rate. Vice versa, the results show those aggregations which are non-prospective, nonsustainable or unsuitable in other ways for Czech agrarian foreign trade in the long term.

\section{RESULTS AND DISCUSSION}

\section{Characteristics of Czech agrarian export competitiveness}

As has been presented in the introductory part of paper, the agrarian export of the Czech Republic has develops dynamically over time. Export and import value and volume are constantly growing. Both the commodity and the territorial structure of agrarian trade are also developing very dynamically.

From the viewpoint of competitiveness on the internal market of the EU countries and on the world market, it is important to stress that in 1993-2009, Czech agrarian export maintained competitiveness in 19 of the 44 analysed items (the export value in the mentioned aggregations reached about $75 \%$ of the value of the total CR agrarian export in the monitored period) on the world market and in case of 22 from the 44 items on the EU market (about 78\% of CR agrarian export only on the market of EU countries). From this it results that almost half theitems of commodity composition of Czech export are competitive (whereas it is just this segment in the commodity structure of Czech agrarian export which represents a decisive part of the actual value of business operations), both on the EU market and also outside this "specific" environment. However, it 
I: Data concerning competitiveness and other selected characteristics of Czech agrarian export (1993-2009)

\begin{tabular}{|c|c|c|c|c|c|c|c|c|c|}
\hline World & $\begin{array}{c}\text { Average } \\
\text { RCA } \\
\text { world } \\
\end{array}$ & $\begin{array}{c}\text { Average } \\
\text { RCA } \\
\text { EU27 } \\
\end{array}$ & $\begin{array}{c}\text { Share } \\
\text { on EU } \\
\text { market }\end{array}$ & $\begin{array}{c}\text { Share on } \\
\text { world } \\
\text { market }\end{array}$ & $\begin{array}{c}\text { EU } \\
\text { share }\end{array}$ & $\begin{array}{c}2008 / 1993 \\
\text { relative } \\
\text { change }\end{array}$ & $\begin{array}{c}2008 / 1993 \\
\text { absolute } \\
\text { change }\end{array}$ & $\begin{array}{c}\text { Total export } \\
\text { value } \\
\text { 1993-2009 } \\
\end{array}$ & $\begin{array}{c}\text { Share in } \\
\text { total export } \\
1993-2009 \\
\end{array}$ \\
\hline S3-001 & 3.206 & 1.9 & $3.93 \%$ & $2.42 \%$ & $90.96 \%$ & 3.09 & 172277771 & 1676782684 & $4.84 \%$ \\
\hline S3-011 & 0.132 & 0.131 & $0.29 \%$ & $0.09 \%$ & $88.38 \%$ & 2.95 & 17644554 & 151112994 & $0.44 \%$ \\
\hline S3-012 & 0.569 & 0.533 & $1.09 \%$ & $0.39 \%$ & $95.72 \%$ & 4.47 & 144228350 & 1210523509 & $3.49 \%$ \\
\hline S3-016 & 0.16 & 0.082 & $0.65 \%$ & $0.40 \%$ & $97.96 \%$ & 71.98 & 17276015 & 49134015 & $0.14 \%$ \\
\hline S3-017 & 0.886 & 0.583 & $2.03 \%$ & $0.93 \%$ & $88.64 \%$ & 6.45 & 102944149 & 593687931 & $1.71 \%$ \\
\hline S3-022 & 3.088 & 1.862 & $4.05 \%$ & $2.22 \%$ & $78.06 \%$ & 4.58 & 514753730 & 3927383821 & $11.34 \%$ \\
\hline S3-023 & 3.103 & 1.407 & $2.03 \%$ & $1.05 \%$ & $66.32 \%$ & 1.27 & 11854781 & 663348616 & $1.91 \%$ \\
\hline S3-024 & 1.057 & 0.323 & $0.71 \%$ & $0.57 \%$ & $58.54 \%$ & 3.87 & 84605586 & 911590385 & $2.63 \%$ \\
\hline S3-025 & 2.023 & 1.316 & $2.89 \%$ & $1.30 \%$ & $87.66 \%$ & 2.07 & 13210959 & 223821266 & $0.65 \%$ \\
\hline S3-034 & 0.445 & 0.85 & $1.05 \%$ & $0.22 \%$ & $96.85 \%$ & 3.7 & 48703829 & 632344944 & $1.83 \%$ \\
\hline S3-035 & 0.05 & 0.067 & $0.27 \%$ & $0.09 \%$ & $96.00 \%$ & 7.01 & 2525123 & 13472952 & $0.04 \%$ \\
\hline S3-036 & 0.005 & 0.017 & $0.04 \%$ & $0.00 \%$ & $97.59 \%$ & 2.44 & 428486 & 5660918 & $0.02 \%$ \\
\hline S3-037 & 0.111 & 0.206 & $0.68 \%$ & $0.13 \%$ & $96.55 \%$ & 4.73 & 13003474 & 102459362 & $0.30 \%$ \\
\hline S3-041 & 1.137 & 1.987 & $6.40 \%$ & $1.05 \%$ & $88.70 \%$ & 16.34 & 248163697 & 1582438171 & $4.57 \%$ \\
\hline S3-042 & 0.199 & 0.719 & $1.11 \%$ & $0.12 \%$ & $85.94 \%$ & 9.03 & 14949459 & 110066612 & $0.32 \%$ \\
\hline S3-043 & 1.411 & 1.477 & $2.82 \%$ & $1.33 \%$ & $89.76 \%$ & 96.39 & 57618819 & 382500978 & $1.10 \%$ \\
\hline S3-044 & 0.228 & 0.504 & $3.16 \%$ & $0.47 \%$ & $98.16 \%$ & 23.16 & 64952619 & 287858604 & $0.83 \%$ \\
\hline S3-045 & 0.793 & 1.437 & $3.52 \%$ & $0.81 \%$ & $88.90 \%$ & 3.05 & 8790085 & 108235916 & $0.31 \%$ \\
\hline S3-046 & 0.868 & 1.423 & $0.68 \%$ & $0.14 \%$ & $74.64 \%$ & 1.43 & 4973382 & 118268052 & $0.34 \%$ \\
\hline S3-047 & 0.175 & 0.361 & $0.23 \%$ & $0.05 \%$ & $91.01 \%$ & 0.54 & -265885 & 5461010 & $0.02 \%$ \\
\hline S3-048 & 2.211 & 1.466 & $2.44 \%$ & $1.29 \%$ & $83.49 \%$ & 6.59 & 383275597 & 2819169058 & $8.14 \%$ \\
\hline S3-054 & 0.881 & 0.62 & $1.53 \%$ & $0.50 \%$ & $72.51 \%$ & 1.91 & 81424494 & 1328181629 & $3.83 \%$ \\
\hline S3-056 & 0.362 & 0.334 & $0.85 \%$ & $0.31 \%$ & $93.64 \%$ & 5.76 & 43598430 & 344633051 & $0.99 \%$ \\
\hline S3-057 & 0.304 & 0.368 & $1.23 \%$ & $0.27 \%$ & $98.20 \%$ & 8.21 & 110457310 & 826894687 & $2.39 \%$ \\
\hline S3-058 & 1.067 & 0.903 & $1.27 \%$ & $0.36 \%$ & $80.22 \%$ & 4.22 & 35852871 & 473531265 & $1.37 \%$ \\
\hline S3-059 & 0.666 & 0.686 & $0.62 \%$ & $0.21 \%$ & $93.63 \%$ & 7.37 & 25209780 & 290233456 & $0.84 \%$ \\
\hline S3-061 & 1.194 & 1.795 & $2.43 \%$ & $0.53 \%$ & $83.97 \%$ & 3.75 & 107721576 & 1253088799 & $3.62 \%$ \\
\hline S3-062 & 3.389 & 3.122 & $6.00 \%$ & $2.37 \%$ & $81.05 \%$ & 8.75 & 163945427 & 1313781542 & $3.79 \%$ \\
\hline S3-071 & 1.101 & 2.19 & $2.33 \%$ & $0.73 \%$ & $88.03 \%$ & 18.16 & 127000583 & 1029336939 & $2.97 \%$ \\
\hline S3-072 & 0.269 & 0.462 & $0.10 \%$ & $0.02 \%$ & $90.92 \%$ & 3 & 551596 & 90498580 & $0.26 \%$ \\
\hline S3-073 & 2.045 & 1.281 & $2.30 \%$ & $1.27 \%$ & $88.85 \%$ & 5.17 & 185344937 & 1429067011 & $4.13 \%$ \\
\hline S3-074 & 0.275 & 0.883 & $1.69 \%$ & $0.26 \%$ & $74.90 \%$ & 10.76 & 17564848 & 70363815 & $0.20 \%$ \\
\hline S3-075 & 0.552 & 1.604 & $1.39 \%$ & $0.19 \%$ & $86.49 \%$ & 1.59 & 2648935 & 72996784 & $0.21 \%$ \\
\hline S3-081 & 0.795 & 1.093 & $1.91 \%$ & $0.46 \%$ & $94.10 \%$ & 6.35 & 225817242 & 1527380945 & $4.41 \%$ \\
\hline S3-091 & 3.608 & 3.314 & $3.19 \%$ & $1.23 \%$ & $91.88 \%$ & 6.28 & 55281188 & 479214196 & $1.38 \%$ \\
\hline S3-098 & 1.635 & 2.526 & $5.98 \%$ & $1.33 \%$ & $71.58 \%$ & 5.04 & 117045002 & 1106798466 & $3.20 \%$ \\
\hline S3-111 & 2.401 & 1.926 & $3.10 \%$ & $1.51 \%$ & $91.59 \%$ & 16.17 & 180137509 & 1214225838 & $3.51 \%$ \\
\hline S3-112 & 1.264 & 1.085 & $1.33 \%$ & $0.65 \%$ & $79.14 \%$ & 3.06 & 233073271 & 2673240015 & $7.72 \%$ \\
\hline S3-121 & 0.098 & 0.267 & $0.50 \%$ & $0.05 \%$ & $85.96 \%$ & 82.04 & 15276716 & 59396289 & $0.17 \%$ \\
\hline S3-122 & 2.535 & 2.114 & $5.69 \%$ & $2.81 \%$ & $87.08 \%$ & 12.04 & 363257897 & 2455719893 & $7.09 \%$ \\
\hline S3-411 & 0.249 & 0.368 & $0.39 \%$ & $0.12 \%$ & $94.65 \%$ & 1.7 & 1638365 & 32243893 & $0.09 \%$ \\
\hline$S 3-421$ & 0.588 & 0.771 & $2.17 \%$ & $0.46 \%$ & $93.86 \%$ & 10.36 & 119001696 & 609778935 & $1.76 \%$ \\
\hline S3-422 & 0.057 & 0.28 & $0.22 \%$ & $0.01 \%$ & $75.46 \%$ & 1.41 & 1007087 & 29022286 & $0.08 \%$ \\
\hline S3-431 & 1.373 & 1.71 & $3.98 \%$ & $0.97 \%$ & $94.86 \%$ & 2.82 & 25876150 & 355975757 & $1.03 \%$ \\
\hline Total & & & & & $84.62 \%$ & 5.04 & 4164647490 & 34640925869 & $2.27 \%$ \\
\hline
\end{tabular}

Source: UN Comtrade, own calculations 

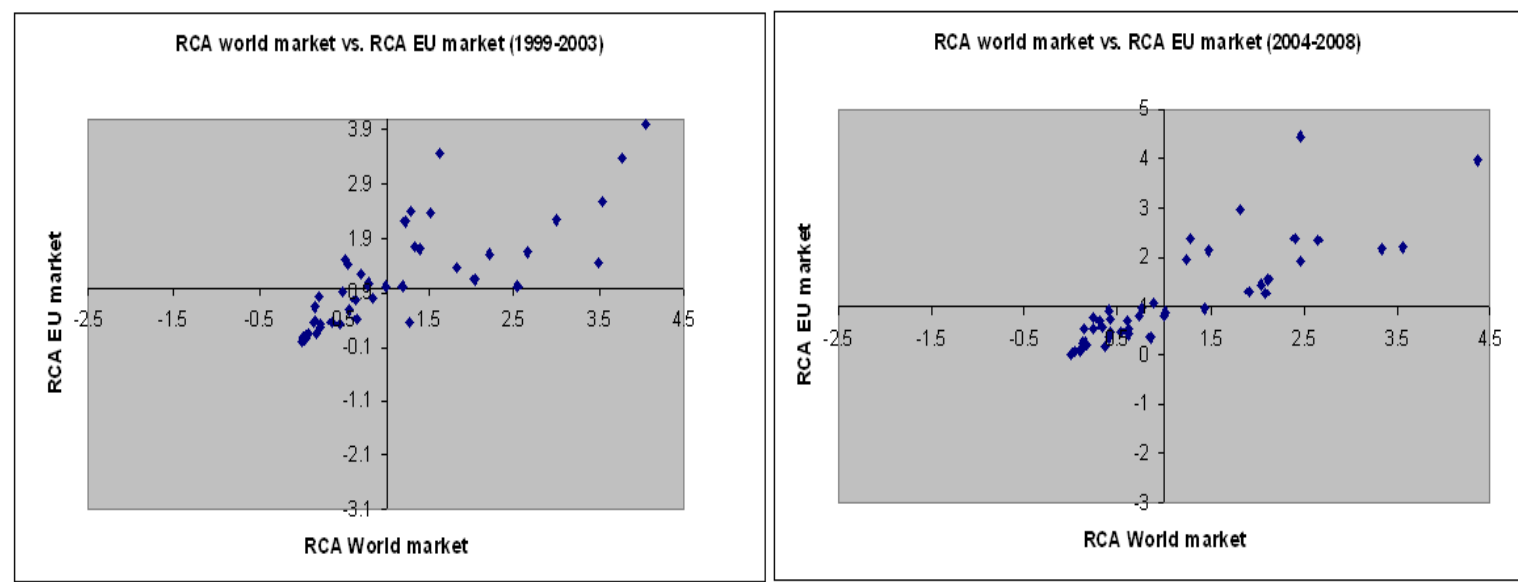

1: Competitiveness of particular aggregations of Czech agrarian export on world market and on market of EU-27 countries in 1999-2003 and 2004-2008

Source: UN Comtrade, own calculations

is necessary to stress that about $85 \%$ of the export value was on the EU-27 market in the monitored period. Detailed information on competitiveness of other selected characteristics of Czech agrarian export are provided in the Table I.

Graph 1 provides a short review of competitiveness of particular items of Czech agrarian export on the EU and world markets. Detailed data concerning the RCA index values for the world market and the EU market can be found in Table II which contains calculations of the RCA index averages over the periods 1993-2009, 1999-2003, 2004-2008 and separately also the values of the RCA index for 2009.

From the viewpoint of the EU internal market it is evident, when comparing the period 1999-2003 with the period 2004-2008/2009, that throughout the years 2004-2009, the commodity structure of Czech agrarian export has started gradually to fall into shape and that more or less particular items of Czech agrarian export have divided into two groups.

The first group includes the items which reach a comparative advantage neither on the internal EU market nor on the world market, and vice versa the second group contains the items of S3-098, S3-062, S3-061, S3-043, S3-041, S3-091, S3-001, S3-022, S3045, S3-071, S3-122, S3-111, S3-073, S3-048, S3-023, S3-025, S3-017, S3-081 a S3-431 which are competitive on the both markets (the number of items which have an uncertain character - i.e. they have a comparative advantage on one market but not on the other market (in comparison with the period 19992003 ) is very low at present.

From these results it is apparent that 19 items of Czech exports are competitive at present (from the viewpoint of both the EU and world markets). Despite the ongoing crisis, which has hit many branches of Czech, European and world economy very negatively, moreover, in 2009, the share of competitive items has been enlarged by aggregations S3081 and S3-431. This analysis confirms the previous assertion that the present (2009) Czech agrarian export relies upon the export of competitive produ- cts from $72 \%$ (3.2 billion USD of the total 4.5 billion USD) (respectively $72 \%$ of value of Czech agrarian export is in competitive aggregations, both on the EU-27 market and the world market).

From this point of view, there are obvious changes which have happened in the period sincethe CR accession to the EU in comparison with the period before the CR joining the EU - i.e. the period 19992003. In the light of competitiveness in this period, the commodity structure of Czech export was considerably fragmented. Many aggregations were competitive neither on the market of the present EU-27 nor on the world market. Vice versa, many aggregations were competitive on both markets, and many other aggregations have an uncertain position regarding the fact that they were for example competitive in the market of the present EU-27, and on the contrary uncompetitive on the world market and vice versa.

The accession to the EU had a positive influence on forming the Czech agrarian trade export structure. The CR became a part of a market where the movement of goods is not limited by the application of protectionist policies. Because other countries joined the EU (some of them important CR business partners) at the same time as the CR, very interesting opportunities for further expansion opened to the Czech agrarian export trade. For one thing the CR became a target of many foreign investments whose main intention was to build a business base in the CR especially for operations of re-export and improving/processing goods and products. The CR also conformed its trade policy not only to rules of the internal EU market, but also entered into EU obligations resulting from negotiations in GATT and WTO.

Many of these engagements opened opportunities for the CR to export its products in many territories - nevertheless, it must be pointed out that some territories were disadvantaged for regarding growth of mutual business, owing to the CR membership in the EU. 
II: RCA index values showing competitiveness of particular aggregations of Czech agrarian export in selected periods

\begin{tabular}{|c|c|c|c|c|c|c|c|c|}
\hline & \multicolumn{2}{|c|}{ 1999-2003 } & \multicolumn{2}{|c|}{ 2004-2008 } & \multicolumn{2}{|c|}{ 1993-2009 } & \multirow{2}{*}{$\begin{array}{c}2009 \\
\text { RCA } \\
\text { world } \\
\end{array}$} & \multirow{2}{*}{$\begin{array}{l}2009 \\
\text { RCA } \\
\text { EU27 } \\
\end{array}$} \\
\hline & $\begin{array}{c}\text { RCA } \\
\text { World } \\
\end{array}$ & $\begin{array}{r}\text { RCA } \\
\text { EU27 } \\
\end{array}$ & $\begin{array}{c}\text { RCA } \\
\text { World } \\
\end{array}$ & $\begin{array}{r}\text { RCA } \\
\text { EU27 } \\
\end{array}$ & $\begin{array}{c}\text { RCA } \\
\text { world }\end{array}$ & $\begin{array}{r}\text { RCA } \\
\text { EU27 } \\
\end{array}$ & & \\
\hline S3-001 LIVE ANIMALS & 2.66 & 1.64 & 3.56 & 2.20 & 3.21 & 1.90 & 3.63 & 1.89 \\
\hline S3-011 BOVINE MEAT & 0.17 & 0.15 & 0.09 & 0.10 & 0.13 & 0.13 & 0.13 & 0.14 \\
\hline S3-012 OTHER MEAT, MEAT OFFAL & 0.56 & 0.57 & 0.61 & 0.54 & 0.57 & 0.53 & 0.58 & 0.53 \\
\hline S3-016 MEAT, ED. OFFL, DRY, SLT, SMK & 0.01 & 0.00 & 0.36 & 0.19 & 0.16 & 0.08 & 0.60 & 0.31 \\
\hline S3-017 MEAT, OFFL. PRPD, PRSVD, NES & 0.46 & 0.34 & 1.01 & 0.80 & 0.89 & 0.58 & 1.39 & 0.98 \\
\hline S3-022 MILK AND CREAM & 2.55 & 1.02 & 3.33 & 2.15 & 3.09 & 1.86 & 3.32 & 1.95 \\
\hline S3-023 BUTTER, OTHER FAT OF MILK & 3.49 & 1.44 & 2.09 & 1.25 & 3.10 & 1.41 & 1.57 & 0.98 \\
\hline S3-024 CHEESE AND CURD & 1.26 & 0.35 & 0.85 & 0.38 & 1.06 & 0.32 & 0.86 & 0.34 \\
\hline S3-025 EGGS, BIRDS, YOLKS, ALBUMIN & 2.04 & 1.15 & 1.44 & 0.93 & 2.02 & 1.32 & 1.95 & 1.39 \\
\hline S3-034 FISH, FRESH, CHILLED, FROZN & 0.49 & 0.92 & 0.33 & 0.56 & 0.44 & 0.85 & 0.33 & 0.51 \\
\hline S3-035 FISH, DRIED, SALTED, SMOKED & 0.01 & 0.02 & 0.09 & 0.10 & 0.05 & 0.07 & 0.13 & 0.13 \\
\hline S3-036 CRUSTACEANS, MOLLUSCS ETC & 0.01 & 0.02 & 0.01 & 0.01 & 0.01 & 0.02 & 0.01 & 0.02 \\
\hline S3-037 FISH ETC. PREPD, PRSVD. NES & 0.08 & 0.13 & 0.15 & 0.27 & 0.11 & 0.21 & 0.19 & 0.33 \\
\hline S3-041 WHEAT, MESLIN, UNMILLED & 1.51 & 2.38 & 1.29 & 2.36 & 1.14 & 1.99 & 1.57 & 3.08 \\
\hline S3-042 RICE & 0.16 & 0.65 & 0.14 & 0.52 & 0.20 & 0.72 & 0.17 & 0.53 \\
\hline S3-043 BARLEY, UNMILLED & 1.41 & 1.72 & 2.40 & 2.38 & 1.41 & 1.48 & 1.99 & 1.36 \\
\hline S3-044 MAIZE UNMILLED & 0.16 & 0.39 & 0.40 & 0.90 & 0.23 & 0.50 & 0.70 & 1.52 \\
\hline S3-045 OTHER CEREALS, UNMILLED & 0.55 & 1.44 & 1.47 & 2.12 & 0.79 & 1.44 & 1.21 & 1.69 \\
\hline S3-046 MEAL, FLOUR OF WHEAT, MSLN & 1.22 & 2.22 & 0.41 & 0.74 & 0.87 & 1.42 & 0.21 & 0.33 \\
\hline S3-047 OTHER CEREAL MEAL, FLOURS & 0.14 & 0.35 & 0.12 & 0.25 & 0.18 & 0.36 & 0.07 & 0.11 \\
\hline S3-048 CEREAL PREPARATIONS & 2.22 & 1.61 & 1.90 & 1.30 & 2.21 & 1.47 & 1.93 & 1.17 \\
\hline S3-054 VEGETABLES & 0.64 & 0.41 & 0.61 & 0.41 & 0.88 & 0.62 & 0.76 & 0.74 \\
\hline S3-056 VEGTABLES, PRPD, PRSVD, NES & 0.36 & 0.34 & 0.41 & 0.36 & 0.36 & 0.33 & 0.47 & 0.41 \\
\hline S3-057 FRUIT, NUTS EXCL. OIL NUTS & 0.23 & 0.28 & 0.42 & 0.47 & 0.30 & 0.37 & 0.41 & 0.59 \\
\hline S3-058 FRUIT, PRESERVED, PREPARED & 1.00 & 1.02 & 0.73 & 0.81 & 1.07 & 0.90 & 0.53 & 0.61 \\
\hline S3-059 FRUIT, VEGETABLE JUICES & 0.85 & 0.81 & 0.54 & 0.45 & 0.67 & 0.69 & 0.31 & 0.30 \\
\hline S3-061 SUGARS, MOLASSES, HONEY & 0.79 & 1.04 & 1.82 & 2.97 & 1.19 & 1.79 & 0.80 & 1.17 \\
\hline S3-062 SUGAR CONFECTIONERY & 4.04 & 4.01 & 4.36 & 3.98 & 3.39 & 3.12 & 3.56 & 2.89 \\
\hline S3-071 COFFEE, COFFEE SUBSTITUTE & 1.63 & 3.46 & 1.24 & 1.97 & 1.10 & 2.19 & 1.10 & 1.12 \\
\hline S3-072 COCOA & 0.70 & 1.24 & 0.15 & 0.21 & 0.27 & 0.46 & 0.04 & 0.05 \\
\hline S3-073 CHOCOLATE, OTH.COCOA PREP & 1.83 & 1.37 & 2.05 & 1.42 & 2.05 & 1.28 & 1.91 & 1.11 \\
\hline S3-074 TEA AND MATE & 0.21 & 0.83 & 0.31 & 0.70 & 0.28 & 0.88 & 0.39 & 0.81 \\
\hline S3-075 SPICES & 0.52 & 1.51 & 0.24 & 0.52 & 0.55 & 1.60 & 0.28 & 0.67 \\
\hline S3-081 ANIMAL FEED STUFF & 0.79 & 1.07 & 0.88 & 1.05 & 0.80 & 1.09 & 0.68 & 0.92 \\
\hline S3-091 MARGARINE AND SHORTENING & 3.77 & 3.38 & 2.65 & 2.34 & 3.61 & 3.31 & 1.84 & 1.54 \\
\hline S3-098 EDIBLE PROD. PREPRTNS, NES & 1.29 & 2.39 & 2.46 & 4.43 & 1.64 & 2.53 & 1.99 & 2.88 \\
\hline S3-111 NON-ALCOHOL. BEVERAGE, NES & 3.54 & 2.58 & 2.12 & 1.53 & 2.40 & 1.93 & 2.26 & 1.49 \\
\hline S3-112 ALCOHOLIC BEVERAGES & 1.19 & 1.01 & 1.02 & 0.88 & 1.26 & 1.09 & 0.97 & 0.64 \\
\hline S3-121 TOBACCO, UNMANUFACTURED & 0.05 & 0.05 & 0.24 & 0.78 & 0.10 & 0.27 & 0.08 & 0.24 \\
\hline S3-122 TOBACCO, MANUFACTURED & 3.01 & 2.26 & 2.46 & 1.91 & 2.53 & 2.11 & 4.20 & 2.74 \\
\hline S3-411 ANIMAL OILS AND FATS & 0.22 & 0.32 & 0.17 & 0.21 & 0.25 & 0.37 & 0.19 & 0.19 \\
\hline S3-421 FIXED VEG. FAT, OILS, SOFT & 0.62 & 0.76 & 0.59 & 0.70 & 0.59 & 0.77 & 0.68 & 1.04 \\
\hline S3-422 FIXED VEG. FAT, OILS, OTHER & 0.02 & 0.08 & 0.02 & 0.08 & 0.06 & 0.28 & 0.01 & 0.11 \\
\hline S3-431 ANIMAL, VEG. FATS, OILS, NES & 1.34 & 1.75 & 0.76 & 0.94 & 1.37 & 1.71 & 1.46 & 1.92 \\
\hline
\end{tabular}

Source: UN Comtrade, own calculations 

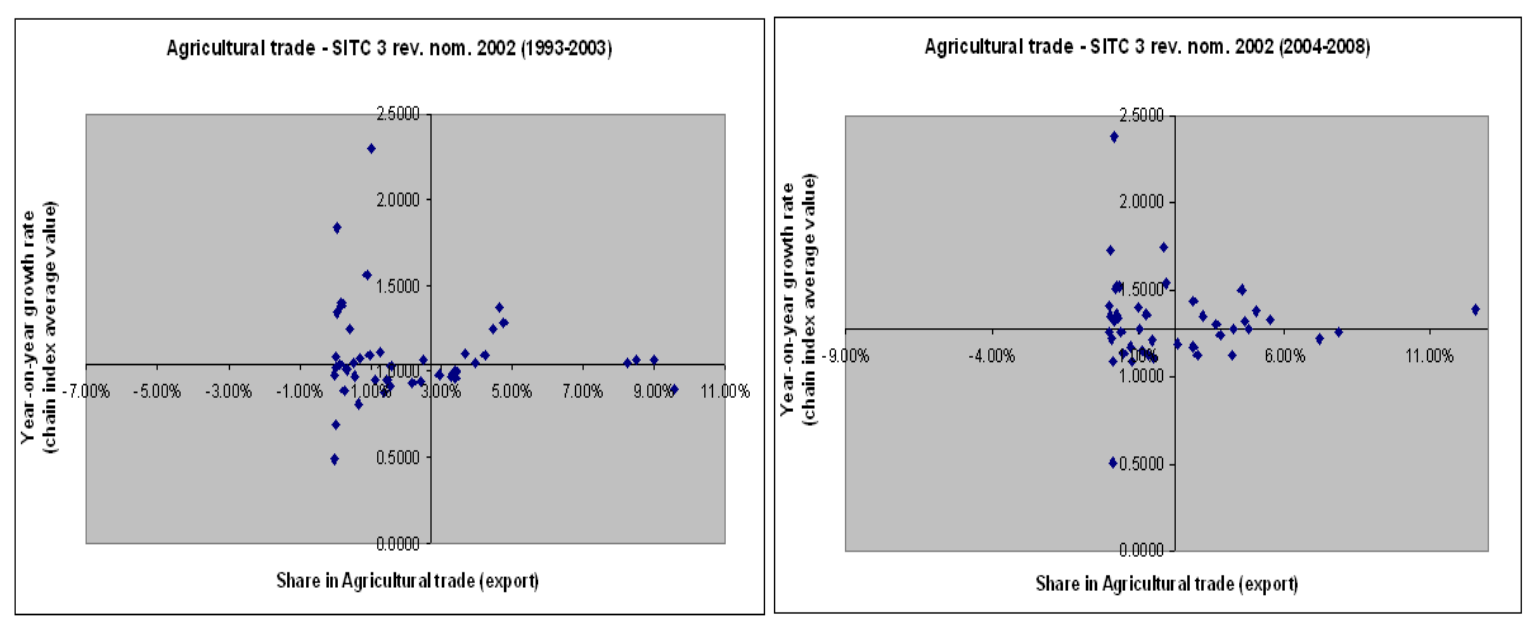

2: Position of particular aggregations of Czech agrarian export in the periods 1999-2003 and 2004-2008 according to share in total agrarian export and value of average year-on-year change (BCG matrix concept) Source: UN Comtrade, own calculations

Graph 2 distributes the individual items (44 aggregations) of Czech agrarian export into four different groups in the form of the BCG matrix. Detailed information on shares in total export and growth rates of value of particular aggregations of Czech agrarian export are given in Table III.

From the viewpoint of composition of Graph 2, the individual aggregations are ranked into four quadrants. The first quadrant includes aggregations representing "stars" (a high share in export and a high year-on-year growth rate of export value); the second quadrant represents the "cash cows" (i.e. aggregations characteristic by a high share in the value of total agrarian export and a low year-on-year growth rate of traded value). The question marks or "problem children" are located in the third quadrant (aggregations characterised by a low share in total agrarian export but their year-on-year growth rate being above average); and the "dogs" are placed in the last fourth quadrant (those items which are characterised by a low share in the exports and a low year-on-year growth rate of traded value). From the perspective of further development it is logical that the export structure should be based in an ideal case on the stars and cash cows; the question marks should indicate a potential for future development, and in the case of the dogs a gradual elimination of their position in the export structure could be expected (these items - if not dealt with by some form of restructuring or adaptation to new conditions should represent only a complement to the export, not its significant part).

If we look at Graph 2 in more detail, we will see that there are obvious differences between both intervals (1999-2003 and 2004-2008). The most important difference can be seen in the average growth rate of export value. While in the period before the accession to the EU the average growth rate of export value was around $4.3 \%$ per year, in the period after the accession it was already $27 \%$ per year. The growth rate multiplied in the case of almost all ana- lysed commodity aggregations (the only exception being aggregation S3-072).

Regarding the concentration of Czech agrarian export between both periods, there are only small differences. The first 15 most important aggregations represent a share in the total value of agrarian export by about $77.45 \%$, and $77.22 \%$, respectively. If we compare these periods, we can see, from the point of view of the position of particular aggregations, the following most important changes: aggregations S3-022, S3-001 and S3-061 strengthened very significantly, whilst shares of aggregations S3-048, S3112 and S3-122 weakened. The commodity structure concentrates more around its medium values in 2004-2008, which corresponded to an average share of individual items in total exports of about $2.27 \%$, and the average growth rate of export value, about $27 \%$ annually per item.

\section{Position of Czech agrarian export in the world market and in the market of EU (EU-27) countries}

If we analyse the competitiveness and position of Czech agrarian exports in the world market and in the EU market, it is not possible to simplify the entire analysis to only focus on an evaluation of the resulting RCA index values. It is also suitable to make this analysis by means of comparison of some important indicators concerning Czech agrarian trade with results of the same indicators characterising the position of agrarian trade (export) on the world market and on the market of the EU-27 countries. In this respect, the following part of this analysis is devoted to the position of Czech agrarian export on the market of the EU-27 countries and on the world market; further differences in the position of particular aggregations of agrarian trade are analysed from both the viewpoint of Czech export and the viewpoint of exports in the EU-27 market, and also from in the light of the world export of agrarian products. 
III: Share in total agrarian trade and growth rate of value of individual aggregations of Czech agrarian export in the periods 1993-2009, 1999-2003, 2004-2008 and in 2009

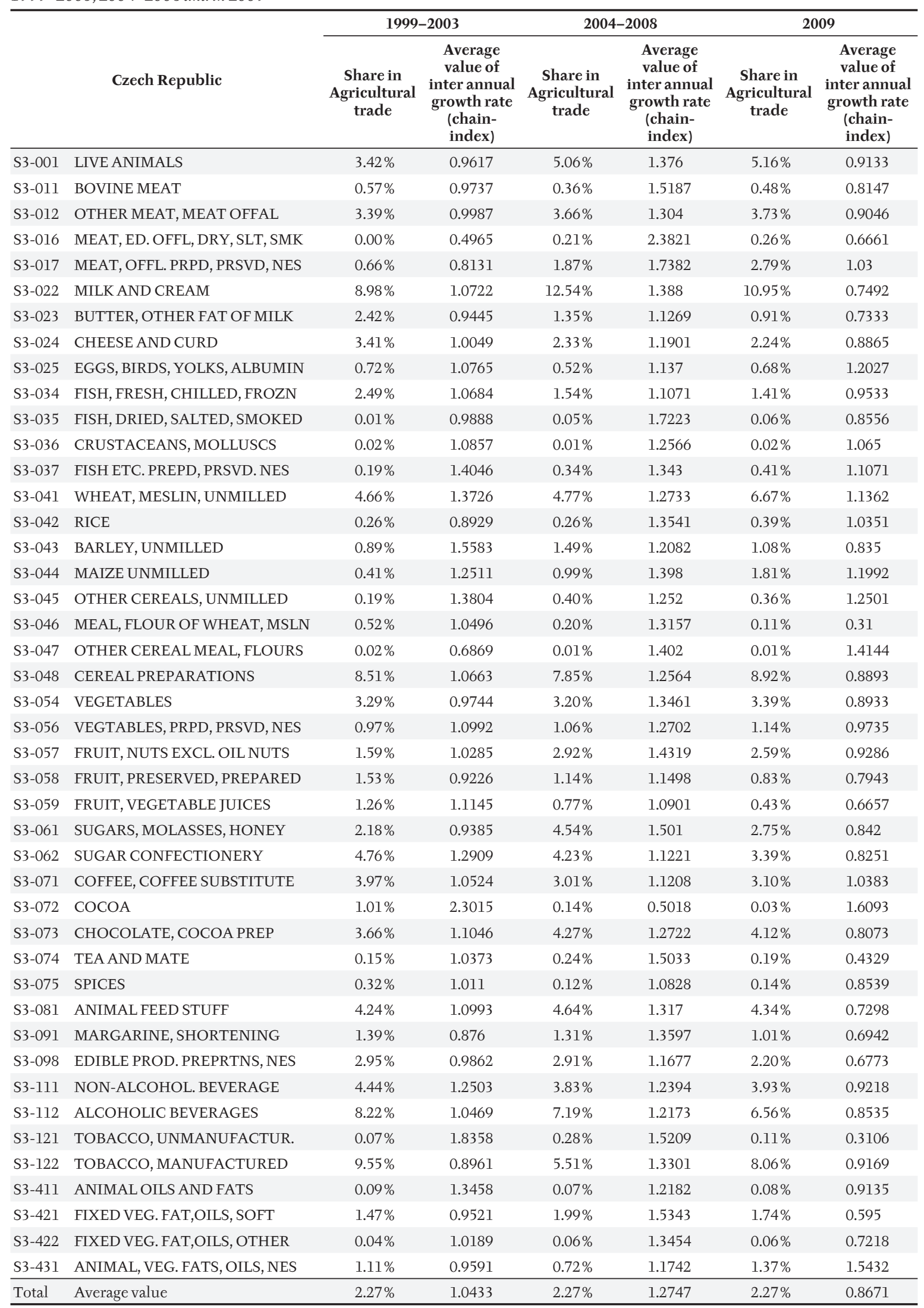

Source: UN Comtrade, own calculations 
If we look at the basic characteristics of Czech agrarian export, we have to state that Czech export is able to win recognition in the world trade, especially in the market of the EU-27 countries which are a natural sales area of Czech export due to the geographic location of the Czech Republic. The Czech Republic represents only $0.15 \%$ of the world's population. As regards GDP, then the CR share in the world GDP is about $0.3 \%$; the share in world trade is about $0.7 \%$ - in case of agrarian trade it reaches about $0.4 \%$ of the world agrarian trade. Regarding the basic proportions of Czech national economy it is evident that in the world and even European structures, Czech agrarian trade will always play only a supplementary role. Nevertheless, if we compare for example growth rates of Czech agrarian export in the period 1999-2009 with growth rates of European and the world agrarian export, we will see that Czech export achieves above-average results. While in the period 1999-2003 the world agrarian export grew in average rate by $3 \%$ yearly, in the case of the market of the EU-27 countries it was 3.7\% yearly - the value of Czech agrarian export increased in the same period by an average of $4.3 \%$ yearly.

Even more significant differences can be seen in the period 2004-2008. In this period, the nominal USD value of world and European agrarian export grew by $14.6 \%$ and $13.5 \%$ respectively per year - in the case of CR agrarian exports it was almost $27.5 \%$. Czech agrarian export also proved a higher stamina concerning the ability to face the world economic crisis. While the export value of EU countries decreased in 2009 in comparison with the 2008 by $40 \%$; in case of the world market it was by about $30 \%$ - Czech agrarian export decreased its dollar value only by less than $14 \%$, whereas a considerable part of this decrease is compensated for by the simple fact of the decrease in exchange rate of Czech crown towards USD, which happened during 2009.

From the viewpoint of commodity structure development, Czech agrarian export tends in many aspects to copy the export structure of the EU-27 countries. This fact then logically results from the geographic location of the CR and further also from similar consumer habits typical for inhabitants of Central and Western Europe who represent more than $70 \%$ of sale of Czech agrarian and food export. Nevertheless, it must be stressed that just similar production conditions and consumer habits, which dominate in this region, also represents a significant problem for further expansion of Czech agrarian export. Most exported products which the Czech Republic achieves in foreign markets are of a purely competitive nature, which means that they have to face considerable competition from similar products from other countries in the EU market.

If we focus more on the comparison of the goods structure of Czech agrarian export with the goods structure of agrarian export in the world and in the EU countries, we will notice the following facts. The CR is competitive as regards the export of most important commodity aggregations which share by more significant rate in the commodity structure of Czech agrarian export. In this respect the Czech export pillar is created by the following commodity aggregations (the share in export value in 2009): S3022 (about 11\%), S3-048 (about 9\%), S3-122 (about 8\%), S3-041 (about 7\%), S3-112 (about 6.5\%), S3-001 (about 5\%), S3-081 (about 4\%), S3-073 (about 4\%), S3111 (about 4\%), and S3-012 (about 4\%). The share of these aggregations in the total export value exceeds $60 \%$ in the long term. It shows that Czech agrarian export is in its nature very concentrated, and its pillar is only a limited number of goods items which in some extent represents an advantage resulting from production specialisation, however, on the other hand it means also a certain threat which constitutes a vulnerability of the present state of export structure, if there were to be an unexpected fluctuation regarding market development in the case of some of the crucial aggregations. From Table IV it can also be seen that Czech agrarian export maintains a high growth rate of value in the long term - as has already been mentioned.

If we look at this development in more detail, we will see that the average dollar value of Czech export increased by about $9.7 \%$ yearly in the period 19932009 , though it must be pointed out that most of this growth took place in 2004-2008 - ie, in the period immediately after the CR accession to the EU. Then, considering the development of export value in the case of the main items creating the pillar of the present Czech agri-food exports, these items (with some exceptions) have continued to increase their export value although in many cases their growth rate was lower than the average growth rate of agrarian export as the whole.

With regard to how the commodity structure of Czech agrarian export copies the commodity structure of EU export in the EU internal market, and also the commodity structure of the world market (respective to the world agrarian market), it can be stated that the commodity structure of Czech agrarian export copies the commodity structure of the world market (measured by conformity of share in the case of particular aggregations in the total agrarian CR export, respective in case of the world market in the total value of agrarian exports realized in frame of the world market) from about 50\%.

From the viewpoint of the CR, the development of commodity structure of the EU-27 market is much more important than the world market development. In comparison of similarity of the commodity structure of the agrarian sector of the EU-27 countries with the commodity structure of CR export, there is a conformity of approximately $70 \%$. 
IV: Development of growth rate of CR agrarian export value (chain index-geometrical mean)

\begin{tabular}{|c|c|c|c|c|c|c|c|}
\hline \multirow{2}{*}{ World } & \multirow{2}{*}{ Total } & \multicolumn{6}{|c|}{ Year on year growth } \\
\hline & & 1993-2009 & $1993-2003$ & 1999-2003 & 2004-2009 & 2004-2008 & $2008 / 2009$ \\
\hline S3-001 & 1676782684 & 1.067 & 0.954 & 0.962 & 1.285 & 1.376 & 0.913 \\
\hline S3-011 & 151112994 & 1.056 & 0.904 & 0.974 & 1.369 & 1.519 & 0.815 \\
\hline S3-012 & 1210523509 & 1.091 & 1.017 & 0.999 & 1.227 & 1.304 & 0.905 \\
\hline S3-016 & 49134015 & 1.274 & 0.688 & 0.496 & 3.554 & 4.968 & 0.666 \\
\hline S3-017 & 593687931 & 1.126 & 0.914 & 0.813 & 1.593 & 1.738 & 1.03 \\
\hline S3-022 & 3927383821 & 1.08 & 0.988 & 1.072 & 1.252 & 1.388 & 0.749 \\
\hline S3-023 & 663348616 & 0.996 & 0.965 & 0.945 & 1.049 & 1.127 & 0.733 \\
\hline S3-024 & 911590385 & 1.08 & 1.05 & 1.005 & 1.133 & 1.19 & 0.886 \\
\hline S3-025 & 223821266 & 1.059 & 1.008 & 1.077 & 1.148 & 1.137 & 1.203 \\
\hline S3-034 & 632344944 & 1.082 & 1.083 & 1.068 & 1.08 & 1.107 & 0.953 \\
\hline S3-035 & 13472952 & 1.118 & 0.926 & 0.989 & 1.533 & 1.722 & 0.856 \\
\hline S3-036 & 5660918 & 1.062 & 0.975 & 1.086 & 1.222 & 1.257 & 1.065 \\
\hline S3-037 & 102459362 & 1.109 & 1.008 & 1.405 & 1.3 & 1.343 & 1.107 \\
\hline S3-041 & 1582438171 & 1.2 & 1.172 & 1.373 & 1.249 & 1.273 & 1.136 \\
\hline S3-042 & 110066612 & 1.15 & 1.071 & 0.893 & 1.295 & 1.354 & 1.035 \\
\hline S3-043 & 382500978 & 1.316 & 1.437 & 1.558 & 1.136 & 1.208 & 0.835 \\
\hline S3-044 & 287858604 & 1.231 & 1.158 & 1.251 & 1.363 & 1.398 & 1.199 \\
\hline S3-045 & 108235916 & 1.087 & 0.999 & 1.38 & 1.252 & 1.252 & 1.25 \\
\hline S3-046 & 118268052 & 0.95 & 0.903 & 1.05 & 1.034 & 1.316 & 0.31 \\
\hline S3-047 & 5461010 & 0.983 & 0.794 & 0.687 & 1.404 & 1.402 & 1.414 \\
\hline S3-048 & 2819169058 & 1.117 & 1.077 & 1.066 & 1.186 & 1.256 & 0.889 \\
\hline S3-054 & 1328181629 & 1.034 & 0.92 & 0.974 & 1.257 & 1.346 & 0.893 \\
\hline S3-056 & 344633051 & 1.114 & 1.057 & 1.099 & 1.215 & 1.27 & 0.973 \\
\hline S3-057 & 826894687 & 1.135 & 1.032 & 1.028 & 1.332 & 1.432 & 0.929 \\
\hline S3-058 & 473531265 & 1.079 & 1.077 & 0.923 & 1.081 & 1.15 & 0.794 \\
\hline S3-059 & 290233456 & 1.105 & 1.17 & 1.115 & 1.004 & 1.09 & 0.666 \\
\hline S3-061 & 1253088799 & 1.074 & 0.931 & 0.938 & 1.363 & 1.501 & 0.842 \\
\hline S3-062 & 1313781542 & 1.131 & 1.173 & 1.291 & 1.066 & 1.122 & 0.825 \\
\hline S3-071 & 1029336939 & 1.201 & 1.262 & 1.052 & 1.107 & 1.121 & 1.038 \\
\hline S3-072 & 90498580 & 1.103 & 1.576 & 2.302 & 0.609 & 0.502 & 1.609 \\
\hline S3-073 & 1429067011 & 1.093 & 1.045 & 1.105 & 1.179 & 1.272 & 0.807 \\
\hline S3-074 & 70363815 & 1.101 & 1.034 & 1.037 & 1.222 & 1.503 & 0.433 \\
\hline S3-075 & 72996784 & 1.019 & 1.006 & 1.011 & 1.041 & 1.083 & 0.854 \\
\hline S3-081 & 1527380945 & 1.101 & 1.048 & 1.099 & 1.194 & 1.317 & 0.73 \\
\hline S3-091 & 479214196 & 1.096 & 1.031 & 0.876 & 1.216 & 1.36 & 0.694 \\
\hline S3-098 & 1106798466 & 1.08 & 1.088 & 0.986 & 1.066 & 1.168 & 0.677 \\
\hline S3-111 & 1214225838 & 1.184 & 1.187 & 1.25 & 1.18 & 1.239 & 0.922 \\
\hline S3-112 & 2673240015 & 1.062 & 1.014 & 1.047 & 1.147 & 1.217 & 0.854 \\
\hline S3-121 & 59396289 & 1.633 & 1.997 & 1.836 & 1.167 & 1.521 & 0.311 \\
\hline S3-122 & 2455719893 & 1.162 & 1.112 & 0.896 & 1.25 & 1.33 & 0.917 \\
\hline S3-411 & 32243893 & 1.028 & 0.956 & 1.346 & 1.161 & 1.218 & 0.914 \\
\hline S3-421 & 609778935 & 1.12 & 1.02 & 0.952 & 1.31 & 1.534 & 0.595 \\
\hline S3-422 & 29022286 & 1.001 & 0.892 & 1.019 & 1.213 & 1.345 & 0.722 \\
\hline S3-431 & 355975757 & 1.096 & 1.024 & 0.959 & 1.229 & 1.174 & 1.543 \\
\hline Total & 34640925869 & 1.097 & 1.041 & 1.043 & 1.195 & 1.275 & 0.867 \\
\hline
\end{tabular}

Source: UN Comtrade, own calculations 


\section{SUMMARY}

Czech agrarian export has very significantly increased its value and volume in recent years. In spite of growing competition it managed, in the analysed years (1993-2009), to maintain a comparative advantage in many aggregations in both the world and European agrarian markets. The European market represents the main sales area for Czech agrarian exports (85\%-90\% of actual export value).

Most export ambitions of Czech trade are concentrated in a few commodity aggregations (about ten of the above-mentioned aggregations) which have a dominant position (of about two-thirds) share in Czech export. On one hand it means a competitive advantage of Czech export, which shows a high specialisation rate, but on the other hand this also represents a certain rate of jeopardy of resulting balance of agri-business if there were to be any paralysis of exports in one or several of those crucial aggregations.

As Czech agrarian export is oriented predominantly on markets having steady economies, where the demand for agrarian products is not directly connected with the development of economic cycle, a better ability to resist the crisis has been proved in the case of the commodity structure of Czech agrarian export. For example the present crisis, which has influenced the world economy and has been evident in the drop of growth of the world economy (production and trade) especially in 2009, had only had a minimum impact on the value of Czech agrarian export. In the case of the world market there is an obvious decrease in export value by about 40\%, and in case of the EU-27 market by about $30 \%$. In the case of Czech agrarian export there was only a decrease of less than 15\% (UN Comtrade). Among other things, it is very important to point out that in the existent commodity structure there is a different ability rate among particular monitored subjects to react to global changes. As has been already above presented, in 1993-2008, the worldwide economy always increased year-on-yearly by several percentage points. The growth of agrarian export value in the case of the EU-27 countries as a whole fell per each percent of world GDP growth by about 1.6\%; in the case of the world market as a whole by about $2 \%$, and in the case of CR agrarian export it was even by $5.8 \%$. This points out that Czech agrarian trade, in the still new conditions of a unified market, continues to develop and looks for its optimal commodity and territorial structures after the fashion of the EU-15 countries whose agrarian sectors have already adapted to the conditions of the common EU market.

\section{SOUHRN}

Analýza konkurenceschopnosti českého agrárního zahraničního obchodu v rámci světového agrárního trhu a v rámci agrárního trhu zemí EU27

Český agrární export v posledních letech velmi výrazně navýšil svou hodnotu a objem. I přes rostoucí konkurenci si dokázal v analyzovaných letech (1993-2009) udržet komparativní výhody v řadě agregací jak v rámci světového, tak i v rámci evropského agrárního trhu. Evropský trh představuje hlavní odbytiště českých agrárních exportů (85\%-90\% hodnoty realizovaných exportů).

Většina exportních ambicí českého obchodu je koncentrována do několika málo komoditních agregací (přibližně deset výše v textu zmíněných agregací), které mají dominantní (přibližně dvoutřetinový) podíl na českém exportu. To na jedné straně představuje konkurenční výhodu českého exportu, který vykazuje vysokou míru specializace, na druhou stranu tento stav představuje i určitou míru ohrožení výsledné bilance agroobchodu v případě, že dojde k jakémukoliv ochromení vývozů realizovaných v rámci jedné, či několika klíčových agregací.

Tím, že je český agrární export orientován převážně na trhy stabilních ekonomik, kde poptávka po agrárních produktech přímo nesouvisí s vývojem ekonomického cyklu, prokázala se v případě komoditní struktury českého agrárního exportu lepší schopnost odolávat krizi. Například současná krize, které ovlivnila světovou ekonomiku a jež se projevila propadem růstu světové ekonomiky (produkce i obchodu) zejména v roce 2009, měla pouze minimální dopad na realizovanou hodnotu českého agrárního exportu. Zatímco v případě trhu světového lze vidět pokles hodnoty exportů přibližně o 40\%, v případě trhu zemí EU27 přibližně o 30\% v případě českého agrárního exportu došlo k poklesu pouze o necelých 15\% (UN Comtrade).

Velmi důležité je mimo jiné podotknout, že v rámci existující komoditní struktury existuje odlišná míra schopnosti mezi jednotlivými sledovanými subjekty reagovat na globální změny. Jakjiž bylo výše řečeno, v letech 1993-2008 celosvětová ekonomika vzrostla vždy meziročně o několik procentních bodů. Na každé procento růstu HDP světa připadal růst hodnoty agrárního exportu v př́ípadě zemí EU27 jako celku přibližně o 1,6\%, v případě trhu světového jako celku přibližně o 2 \% a v případě agrárního exportu ČR to bylo dokonce o 5,8\%. Tento stav pak ukazuje na skutečnost, že se český agrární obchod v pro něj stále ještě nových podmínkách jednotného trhu neustále dynamicky vyvíjí a hledá svoji optimální jak komoditní, tak i teritoriální strukturu po vzoru zemí EU15, jejichž národní agrární sektory se již přizpo̊sobily podmínkám společného trhu EU.

konkurenceschopnost, agrární obchod, Česká republika, svět, EU, analýza, komoditní struktura 
Acknowledgment

This paper is apart of a research project being undertaken by the authors on the topic of the "Economics of resources of the Czech agriculture and their efficient use in the frame of multifunctional agrifood systems" grant No. 6046070906, funded by the Czech Ministry of Education, Youth and Sports of the Czech Republic.

\section{REFERENCES}

BALASSA, B., 1965: "Trade liberalization and 'revealed' comparative advantages", The Manchester School of Economic and Social Studies, Vol. 32, No. 2, pp. 99-123.

EUROPEAN COMMISSION, 2010: Agricultural trade statistics, EUROSTAT database, available at: http://eabouteuropa.eu/agriculture/agrista/tradestats/index_en.htm, retrieved:08/08/2010.

JENÍČEK, V., KREPL, V., 2009: The role of foreign trade and its effects, Agric. Econ. - Czech, 55, 2009 (5): 211-220, ISSN: 0139-570X.

KOTLER, P., 2007: Principles of Marketing, Fourth European Edition, Grada 2007, ISBN: 978-80-2471545-2, EAN: 9788024715452.

KRUGMAN, P. R., OBSTFELD, M., 2006: International Economics - theory and policy, Pearson Education, Inc., Boston 2006, ISBN 0-321-31154-X.
SVATOŠ, M., 2008: Selected trends forming European agriculture, Agric.Econ.-Czech, 54, 2008, ISSN: 0139-570X.

TOMŠÍK, K., ROSOCHATECKÁ, E., 2007: Competitiveness of the Finnish Agriculture after ten years in the EU, Agric. Econ. - Czech, 53, 2007 (10), ISSN: 0139-570X.

UTKULU, U. AND SEYMEN, D., 2004: Revealed Comparative Advantage and Competitiveness: Evidence for Turkey vis-à-vis the EU/15. Paper to be presented at the European Study Group 6th Conference, ETSG 2004.

UNITED NATIONS ORGANIZATION, database UN Comtrade, 2010, available at: http://comtrade.un.org/db/dqQuickQuery.aspx, retrieved: 08/08/2010.

prof. Ing. Miroslav Svatoš, CSc., Ing. Luboš Smutka, Ph.D., Katedra ekonomiky, Česká zemědělská univerzita v Praze, Kamýcká 129, Praha 6 - Suchdol, 16521 Praha, Česká republika, e-mail: svatos@pef.czu.cz, smutka@pef.czu.cz 